\title{
ACE2 wt Allele
}

National Cancer Institute

\section{Source}

National Cancer Institute. ACE2 wt Allele. NCI Thesaurus. Code C102528.

Human ACE2 wild-type allele is located in the vicinity of Xp22 and is approximately $41 \mathrm{~kb}$ in length. This allele, which encodes angiotensin-converting enzyme 2 protein, is involved in both peptide hormone-processing and vasodilation. 